\title{
A koronavírus járvány hatása a villamosenergia-rendszerre mint kritikus infrastruktúrára
}

\author{
Aszódi Attila*, Biró Bence \\ Budapesti Műszaki és Gazdaságtudományi Egyetem, Nukleáris Technikai Intézet, Budapest, Magyarország
}

Beérkezett: 2021. május 26.; Elfogadva: 2021. július 16.

\begin{abstract}
Összefoglalás
Írásunk a magyar villamosenergia-rendszert vizsgálja a COVID-19 koronavírus-járvány időszakában. Bemutatjuk a járvány magyarországi alakulásának villamosenergia-fogyasztásra gyakorolt hatását. Elemezzük a magyar villamosenergia-fogyasztási adatokat a 2019. és a 2020. év vonatkozásában, összehasonlítjuk a fogyasztás és a GDP negyedéves változását 2020-ban, és összevetjük a magyar villamosenergia-rendszerben bekövetkezett változásokat egyes európai országok rendszerének adataival. Cikkünk végén röviden bemutatjuk a villamosenergia-rendszer mint kritikus infrastruktúra múködtetésének mindennapjait a járvány alatt, amely rendszer ebben a mindenki számára megerőltető időszakban is folyamatosan biztosította a fogyasztók biztonságos és megbízható villamosenergia-ellátását.
\end{abstract}

Kulcsszavak: koronavírus-járvány, villamos energia, ellátásbiztoság, kritikus infrastruktúra

\section{Impact of the coronavirus pandemic on the electricity system as critical infrastructure}

\author{
Attila Aszódi, Bence Biró \\ Budapest University of Technology and Economics, Institute of Nuclear Techniques, Budapest, Hungary
}

\begin{abstract}
Summary
The pandemic situation caused by the coronavirus has momentarily changed the lives of everyone in the world. With the closure of borders and the imposition of curfews, tourism practically stopped overnight, civil aviation shut down, offices and some manufacturing plants closed, people were forced to stay in their homes for months, worldwide. It must also be taken into account that intensive air travel and a globalised world economy clearly predispose the world to a greater frequency of pandemics in the future, and that society, the country and humanity as a whole must be prepared to deal more effectively with similar epidemics. This salutatory change is certainly worth analysing, as much can be learned from the current situation.

In this article, we analyse the energy aspects of the epidemic, as the virus has left a deep imprint even in this industry. For the analysis, it is essential to describe the behavior of the COVID-19 pandemic in Hungary and the measures taken in parallel to contain the outbreak, as these measures have had a significant impact on the country's electricity system. We examined the electricity consumption trends for 2020 compared to 2019. We show how the consumer sides of different European electricity systems have reacted to the situation. We conclude by highlighting the changes in the critical energy infrastructure that, despite the difficulties caused by the epidemic, the Hungarian electricity system has provided the population with the electricity which is increasingly essential to our daily lives.

The current situation highlights even more that the main infrastructures of modern societies, such as industrial production plants, transport, commerce, health care, information technology and even households, cannot function without a reliable and secure electricity supply. It is therefore of paramount importance to ensure the operational conditions of the electricity system as critical infrastructure, even during a pandemic.
\end{abstract}

Keywords: coronavirus pandemic, electricity, security of supply, critical infrastructure 


\section{Bevezetés}

A koronavírus okozta pandémiás helyzet pillanatszerúen változtatta meg a világon élő minden ember életét. Az országhatárok lezárásával és a kijárási korlátozás bevezetésével a turizmus gyakorlatilag egyik napról a másikra megszúnt, a polgári repülés leállt, az irodák, bizonyos gyártóüzemek bezártak, az emberek hónapokra az otthonukba kényszerültek, világszerte. Azt is figyelembe kell venni, hogy az intenzív légi közlekedés és a globalizálódott világgazdaság egyértelmúen predesztinálja a világot arra, hogy a jövôben világjárványok nagyobb gyakorisággal következzenek be, így a társadalom, az ország és az egész emberiség felkészítése szükséges a hasonló járványhelyzetek hatékonyabb kezelése érdekében. Ez az ugrásfügggvényszerú változás mindenképpen analízisre érdemes, hiszen a mostani helyzetből sokat tanulhatunk a múltbeli és a jövőbeli folyamatokra vonatkozóan.

Cikkünkben a járvány energetikai vonatkozásait elemezzük, hiszen a vírus még ebben az iparágban is mély nyomott hagyott. Az elemzéshez elengedhetetlen, hogy bemutassuk a COVID-19 magyarországi lefutását, és ezzel párhuzamosan a járvány megfékezéséért tett intézkedéseket, hiszen ezen intézkedések jelentős hatással voltak az ország villamosenergia-rendszerére. Megvizsgáltuk a 2020. év áramfogyasztási trendjeit a 2019. év adataihoz képest. Bemutatjuk, hogy a különböző európai villamosenergia-rendszerek fogyasztói oldala hogyan reagálta le a kialakult helyzetet. Írásunk végén azon kritikus energetikai infrastruktúrában bekövetkezett változásokat mutatjuk be, amelyek a járvány következtében fellépó nehézségek ellenére ellátta a magyar lakosságot a mindennapjainkban egyre jobban nélkülözhetetlen villamos energiával.

A jelenlegi helyzet még inkább felhívja a figyelmet arra, hogy a modern társadalmak fó infrastruktúra-elemei, mint az ipari termelöüzemek, a közlekedés, a kereskedelem, az egészségügyi rendszer, az informatika, de a háztartások sem képesek múködni megbízható és biztonságos villamosenergia-szolgáltatás nélkül. Ezért kiemelt jelentőségû a villamosenergia-rendszer mint kritikus infrastruktúra múködési feltételeinek biztosítása még pandémia alatt is.

\section{COVID-19-járvány Magyarországon}

Talán nem túlzás megelőlegezni azt a kijelentést, hogy a ma élő generációk emlékeiben a COVID-19 világjárvány okozta sokk és megrázkódtatás olyan mély élményként fog megmaradni, mint amilyen korábban a II. világháború vagy az 1956-os forradalom volt. Évtizedekre visszamenően nem tudunk olyan eseményt mondani, ami olyan sok embert és olyan nagy mértékben érintett, mint a járvány. Utólag is érdekes, hogy 2020 január-februárjában még csak különleges egzotikumként tekintettünk arra, amit a Kínában történtekról írt a világsajtó, majd március közepén egyik napról a másikra átbillent az európai járványhelyzet, és kényszerültek európai kormányok arra, hogy sorra egyre szigorúbb utazási, majd kijárási korlátozásokat vezessenek be.

A járvány első hullámának megfékezése érdekében hozott korlátozások ugrásszerú változásokat hoztak az egyes országok múködésének mindennapjaiba. Nem volt ez másképp Magyarországon sem, ahol 2020. március ll-én, egy szerdai napon, az esti órákban megjelent kormányrendelet következtében diákok milliói ismerkedtek meg egyik napról a másikra a távolléti oktatás fogalmával és eszközeivel, valamint a dolgozók jelentős része kényszerült a munkáját a megszokott irodai környezetétól távol, az otthonából végezni.

Míg az egyének számára az első hullám történései aggasztóak voltak, utólag azt mondhatjuk, hogy a megbetegedési számok nagyon alacsonyan maradtak a második és harmadik hullám számaihoz képest. Ahogy az 1. ábra mutatja, az első hullám számai eltörpülnek a második és a harmadik hullám epidemiológiai számaihoz képest. A második hullám görbéjének exponenciális felfutása már-már egy megszaladt reaktor teljesítménynövekedéséhez hasonlított. A második hullámban az aktív fertőzöttek számát bemutató görbe (az 1 . ábrán sárgával jelölve) 2020. december 20-án tetőzött, majd ezután csökkenésnek indult, ami azt jelenti, hogy az újabb járványügyi korlátozások sikeresen visszaszorították a járvány további rohamos terjedését.

A harmadik hullám ugyanakkor még nagyobb erôvel csapott le nemcsak hazánkra, hanem egész Európára, amely országunkban mind az aktív fertőzöttek számában, mind a napi új megbetegedések esetén új csúcsokat jelentett, valamint azt is, hogy az első hullám adatai már annyira eltörpülnek az l. ábrán, hogy szinte alig észrevehetőek. Érdemes megfigyelni az ábrán a három egymás utáni hullám lefutását is, melyekről megállapítható, hogy a lefutásuk csak abszolút értékben különbözik, jellegüket tekintve rendkívül hasonlóak. Jelen cikk véglegesítésekor (2021. május közepe) a harmadik hullám leszálló ágában vagyunk, köszönhetően a napról napra növekvő, Európában kiemelkedő magyarországi átoltottsági aránynak.

Habár a járvány eddigi három hulláma a megbetegedések számát tekintve jellegében hasonló lefutást mutat, a járványkezelésben jelentős különbségek voltak, amelyek komoly hatást gyakoroltak a gazdaság minden szektorára, ezen keresztül pedig a villamosenergia-rendszerre is. Az első hullám során az európai országok (néhány hetes különbséggel) 2020 márciusában kijárási korlátozásokat vezettek be, így igyekeztek korlátozni az emberek közötti kontaktusokat. Az első hullámban ez nemcsak a turizmus leállitását, valamint az iskolák és irodák bezárását jelentette, hanem sok esetben fontos és nagy kapacitású termelőüzemek múködésének felfüggesztését is. Ez radikális hatást gyakorolt az európai gazdaságok teljesítményére és a villamosenergia-igényekre is.

A 2. ábrán azt mutatjuk be, hogy 2020 négy negyedéve során hogyan változott Magyarország gazdasági teljesítménye, GDP-je a 2019. év azonos időszakához ké- 


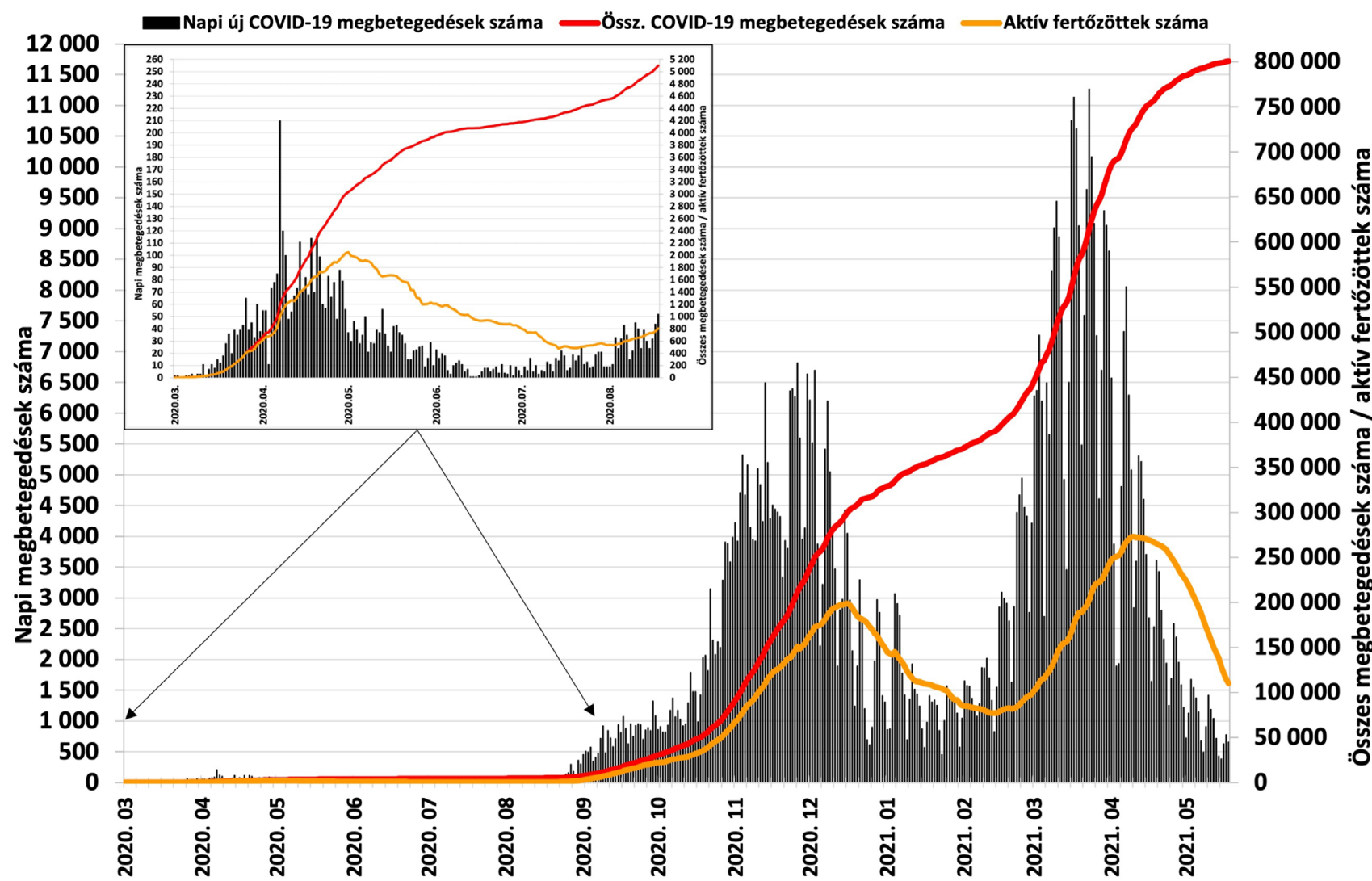

1. ábra

Az összesített és a napi új COVID-19 megbetegedések, valamint az aktív fertőzöttek számának alakulása Magyarországon 2020. 03.04. és 2021. 05. 21. között (Magyarország Kormánya 2021, saját szerkesztés)

pest. Az ábrában azt is feltüntettük, hogy ezzel együtt hogyan változott az ország villamosenergia-fogyasztása. Az ábra rendkívül szemléletesen mutatja, hogy habár a járvány eddigi három hulláma közül az első volt a legenyhébb a megbetegedések száma tekintetében, a gazdaságra ez gyakorolta a legnagyobb negatív hatást: amíg az első negyedévben 2\%-os növekedés volt megfigyelhetô, addig a második negyedévben a magyar GDP 13\%-ot meghaladó mértékben esett vissza, ami - ha a növekedési potenciált is figyelembe vesszük - összesen $15 \%$ körüli visszaesést jelent (KSH 2021). És bár a második járványhullám 2020 őszén sokkal nagyobb volt epidemiológiai szempontból, mint az első, mégis a harmadik és negyedik negyedév gazdasági visszaesése 2019-hez képest 5\% alatt maradt (KSH 2021). Ez nyilván egyrészről annak köszönhető, hogy a járvány kezelésére eltérő intézkedéseket vezettek be, valamint talán annak is, hogy az emberek és a gazdasági szereplók is adaptálódtak a megváltozott helyzethez, és idővel kialakították azokat a mechanizmusokat, amelyek alkalmazásával - ha csak részben is, de - fenn lehetett tartani a múködés egy részét.

Mind a járvány, mind pedig a járványhoz való adaptálódás, a járvány kezeléséhez használt eszközök változása jelentős hatást gyakorolt a villamosenergia-igényekre. Szintén a 2. ábrán figyelhetjük meg, hogy míg a járvány első hulláma alatt, 2020. második negyedéve során a magyar villamosenergia-fogyasztás $9,5 \%$-kal esett vissza 2019. második negyedévéhez képest, mindeközben 2020. harmadik negyedévében $2 \%$ alatti maradt a visszaesés, még a negyedik negyedév 3,5\%-ot meghaladó áramigény-növekedést hozott (MAVIR 2021 webhelyen elérhető adatok alapján). A napról napra megdőlő villamosenergia-fogyasztási adatokat figyelve 2020 végén kifejezetten az volt az érzésünk, hogy a gazdaság szereplői keményen dolgoztak azon, hogy az első hullám során elszenvedett visszaesést ledolgozzák.

\section{A magyar villamosenergia-rendszer a járvány idején}

Vizsgáljuk meg részletesebben a villamosenergia-fogyasztási adatokat a COVID-19 járvány időszakában. Ahogy fentebb említettük, a kijárási korlátozások bevezetése jelentős mértékben befolyásolta Magyarország villamosenergia-felhasználását. A 2. ábrán bemutatottnál nagyobb felbontású képet kaphatunk, ha megvizsgáljuk a 3. ábrán látható adatokat és trendeket. Az ábra heti bontásban tartalmazza a 2020. és a 2021. év heti villamosenergia-fogyasztási adatait. Fontos megjegyezni, hogy a heti adatok összeállítása során ragaszkodtunk a hetek ritmusához (minden hét hétfőtől vasárnapig tart), 


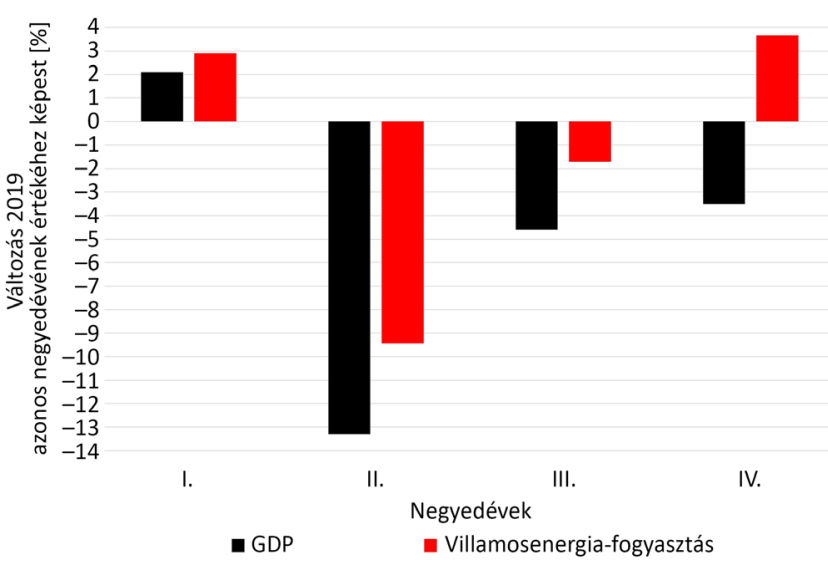

2. ábra

A 2020. év negyedéves GDP és a villamosenergia-fogyasztás változása 2019 azonos időszakának értékeihez viszonyítva ( $K S H$ 2021 és MAVIR 2021 alapján saját szerkesztés)

mert a heteken belüli napi villamosenergia-fogyasztások illeszkednek az emberek és a gazdaság napi és heti ritmusához. Ez azt jelenti, hogy nem kapnánk jól összevethető adatokat, ha egy adott év heti (hétnapos) felbontású adatainak gyüjtését mindig január l-től kezdenénk, hiszen az egyes években január l. a hét eltérő napjára esik. A vizsgált 2019., 2020. és 2021. évek esetében mindhárom év első hete tartalmazott még olyan napot, ami a korábbi naptári évhez tartozik. Így a jelen cikkben szereplő kiértékelések során 2019. év első hetének a 2019. 01. 07. nappal kezdődő hetet vettük, a 2020. év első hetének a 2020. 01. 06. nappal kezdődő teljes hetet, a 2021. év első hetének pedig a 2021. 01. 04. nappal kezdődő hetet.

A 3. ábra lefutásából jól látható, hogy a járvány előtt nagyjából a 10. hétig a 2020. évi fogyasztás meghaladta a 2019. évi értékeket. A kijárási korlátozás életbe lépésének hetében (12.) már kevesebb volt a heti fogyasztásunk, mint 2019 azonos hetében, és a következő hetekben egy ugrásszerü csökkenés figyelhető meg. A legnagyobb csökkenés a 14. héten következett be, amikor 14,52\%-kal fogyasztottunk kevesebb villamos energiát egy hét alatt, mint 2019-ben (MAVIR 2021 webhelyen elérhető adatok alapján). Fontos ezen a helyen megjegyezni, hogy a villamosenergia-igényeket a hetek és a napok változása mellett jelentősen befolyásolja - többek között - az időjárás, a környezeti hőmérséklet változása, valamint az ünnepnapok. Ez itt azért különösen fontos, mert 2020-ban éppen az előbb említett 14. hétre esett a húsvét, míg 2019-ben a 15. hétre.

Az ezt követő három hónapban - bizonyos ingadozásokkal ugyan, de - jellemzően 10\%-ot megközelítő villamosenergia-igény csökkenés figyelhető meg a 3. ábrán. A 26. héttől a 4l. hétig egy stagnáló villamosenergiafogyasztási változás látható, leszámítva az augusztusi 33-35. heteket, amikor is 9\%-ot megközelítő visszaesés jelentkezett. Ez az időszak az augusztus 20-i nemzeti ünnephez kapcsolódó hosszú hétvége időszaka, amikorra nagyon sokak nyári szabadsága kötődött. Azt lehet megállapítani ezekból az adatokból, hogy 2020 augusztusának ezen három hetére jobban koncentrálódott a magyarok nyaralása és ezzel párhuzamosan a termelés

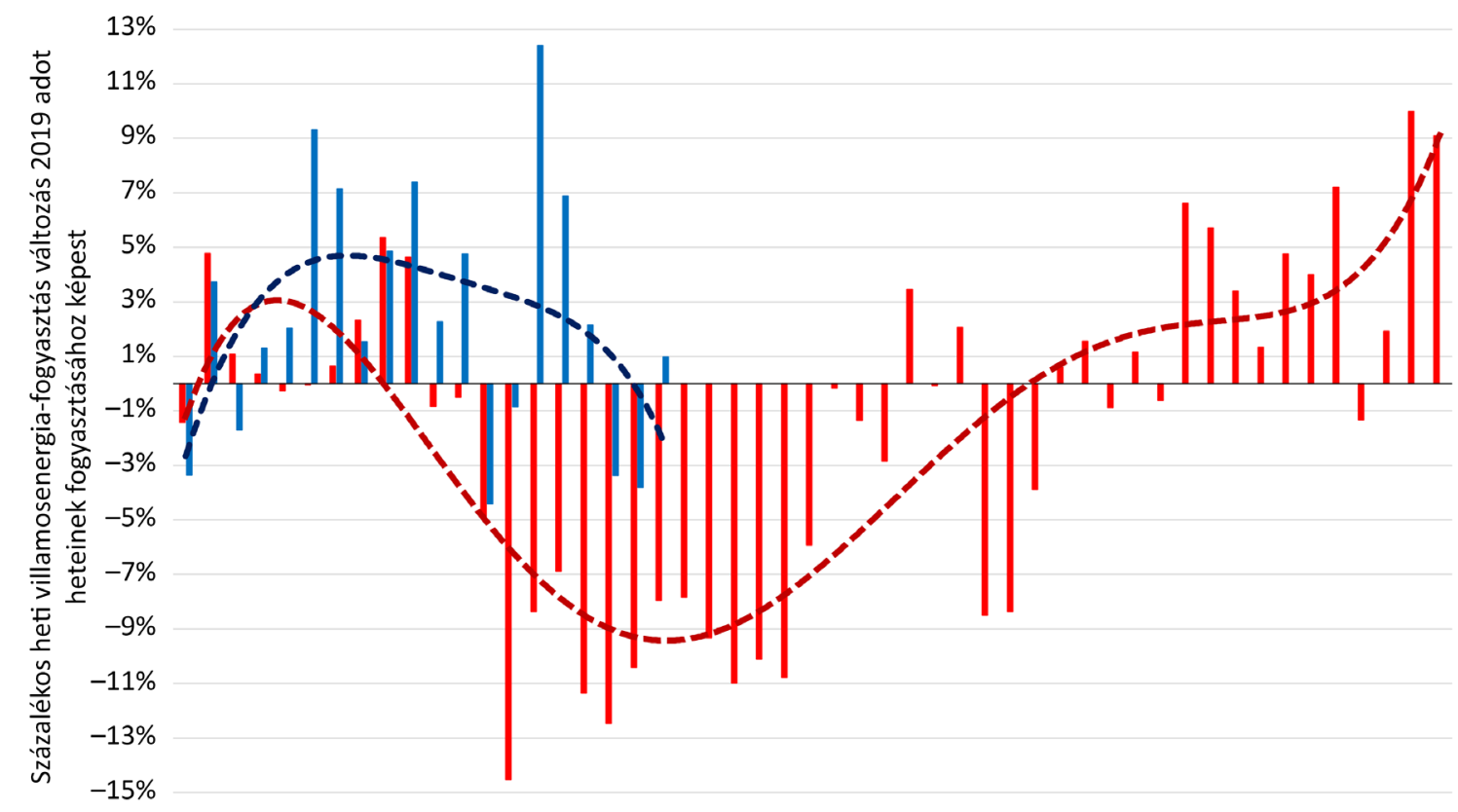

1. 3. 5. 7. 9. 11. 13. 15. 17. 19. 21. 23. 25. 27. 29. 31. 33. 35. 37. 39. 41. 43. 45. 47. 49. 51. Hetek sorszáma

—2020 — 2021

3. ábra | 2020 és 2021 adott heti fogyasztásának százalékos változása 2019 azonos heti fogyasztásához viszonyítva (MAVIR 2021 alapján saját szerkesztés) 
időleges visszaesése, mint az volt a 2019. évben. Az év utolsó közel három hónapjában a 2019. évi adatokat jelentősen meghaladó fogyasztási adatokat láthatunk (a maximum az 50. héten mérhető, amikor a 2020. évi fogyasztás 9,97\% értékkel haladta meg a 2019. évi értéket), ami azt mutatja, hogy a járvány nagyon intenzív és embert próbáló második hulláma alatt is magas szinten maradt a villamosenergia-igény (MAVIR 2021 webhelyen elérhető adatok alapján).

A 2021. évi adatokat vizsgálva egyértelmúen kijelenthető, hogy az év elejei fogyasztás gyengébb volt, mint 2020 első heteiben, azonban rendkívül látványos a különbség az ezt követő hetekben, hiszen annak ellenére, hogy mindkét évben (2020 és 2021) azonos héten (12.) kerültek bevezetésre járványügyi korlátozások, 2021 egyetlen hetében sem látható komolyabb fogyasztási visszaesés 2019 azonos heteihez képest, míg - ahogy fent taglaltuk - 2020 tavaszán az első hullám alatt a korlátozások jelentősen visszavetették a gazdaságot. A 2021. év tekintetében kivételként kell említenünk a 13. hetet, amikor a 2021-es húsvéti ünnepek alatt 4,41\%-kal kevesebb volt a fogyasztás, mint a 2019. év 13. hetében (MAVIR 2021). A 2021. év 15. hetének kiugróan magas fogyasztásnövekedésének elsődleges magyarázata, hogy a referenciaévként használt 2019. évben a 15. héten voltak a húsvéti ünnepek. Azt ugyanakkor mindenképpen kijelenthetjük, hogy a 2021. év februárja és májusa között zajló harmadik járványhullám alatt nem esett vissza a villamosenergia-fogyasztás, sőt 2019-hez képest számottevő növekedés volt megfigyelhető. A MAVIR weblapján elérhető adatok feldolgozása során azt találtuk, hogy amíg a 2020. év február, március és április havi hazai villamosenergia-fogyasztási adatai a 2019. év azonos hónapjához képest $+3,61 \%,+2,11 \%$, illetve $-9,09 \%$ változást mutattak, addig 2021-ben szintén a 2019. év azonos hónapjához viszonyítva $+4,55 \%,+4,76 \%$ és +2,96\%-os növekedést figyelhetünk meg (MAVIR 2021 webhelyen elérhető adatok alapján)

Ezek az adatok is azt támasztják alá, hogy az eltérő járványkezelés, az ország, a kormányzat, az állampolgárok és a gazdasági szereplők adaptációs folyamatai következtében a COVID-19 járvány második és harmadik hulláma során a visszaesés sokkal kisebb volt, mint az első hullám esetében, sőt a villamosenergia-fogyasztás még növekedett is a harmadik hullám során a referenciaévnek tekinthető 2019-hez képest.

A 4. ábrán a pillanatnyi villamosenergia-fogyasztás heti maximális és minimális értékének alakulását ábrázoltuk a 2019., 2020. és 2021. évre. Itt is jól látható, hogy a rendszerterhelés az első hullám alatt (2020 tavaszán és nyarán) jelentősen elmaradt a 2019. évi adatoktól, ugyanakkor a - megbetegedések szempontjából sokkal jelentősebb - harmadik hullám alatt, 2021 tavaszán a rendszerterhelési adatok nagyon hasonlóan alakultak, mint a járvány által érintetlen 2019. évben. Érdemes megfigyelni azt is, hogy a második hullám alatt, 2020 decemberében a 48 . héten a járvány ellenére majdnem megdőlt a rendszerterhelési rekord: csak $10 \mathrm{MW}$-tal maradt el azon a héten a csúcsigény a 2019. év 48. heti 7105 MW-os értékétől. Ezt követően azonban nem kellett sokat várni az új csúcsra, hiszen 2021. 6. hetében (lásd a 4. ábrában kék négyzetben jelölve) 7119 MW-tal

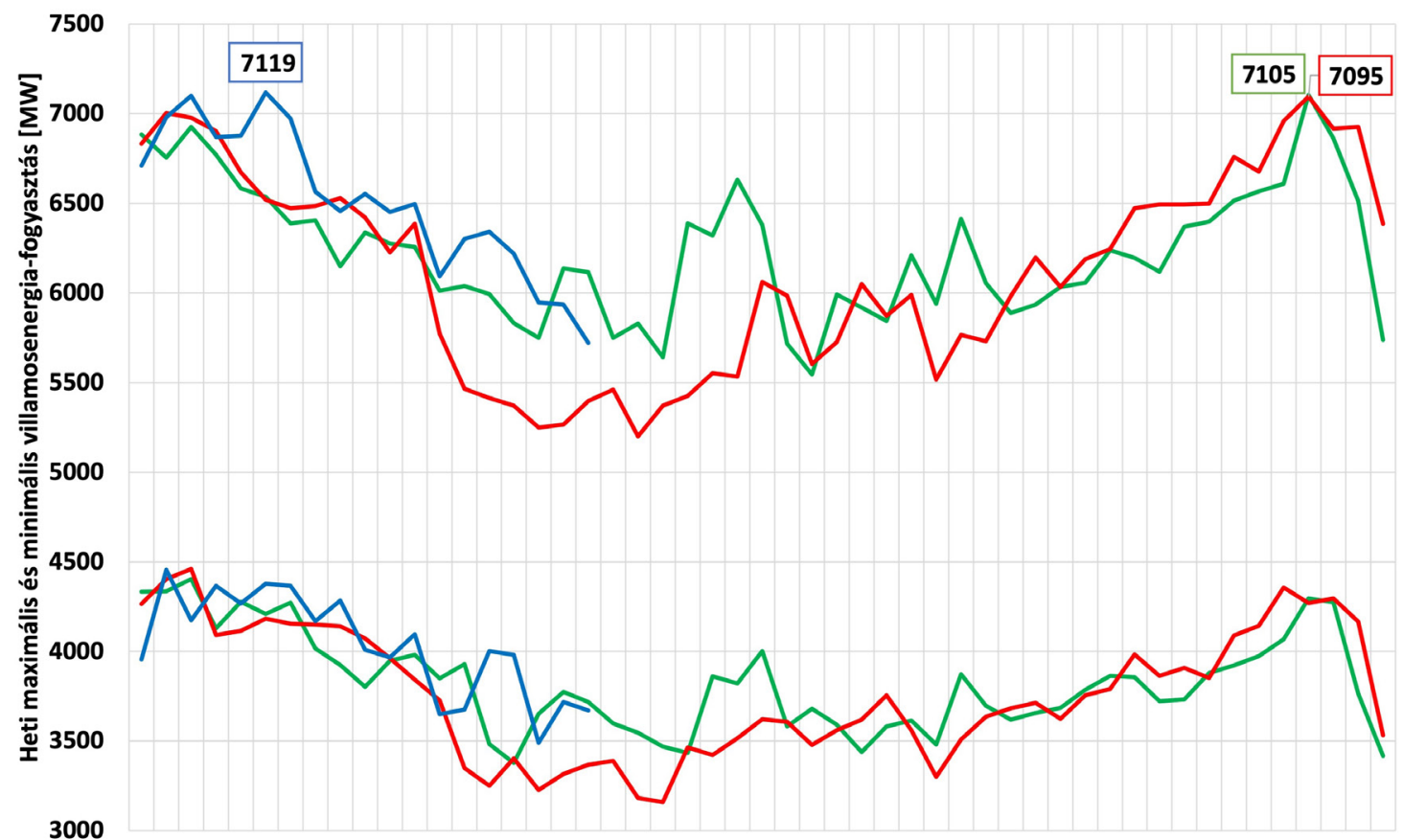

1. 3. 5. 7. 9. 11. 13. 15. 17. 19. 21. 23. 25. 27. 29. 31. 33. 35. 37. 39. 41. 43.45 .47 .49 .51$. $2019-2020 \longrightarrow 2021$

4. ábra | A magyar villamosenergia-rendszer maximális és minimális rendszerterhelése heti bontásban (2019-2021) (MAVIR 2021 alapján saját szerkesztés) 
új rendszerterhelési rekord született a magyar villamosenergia-rendszer történelmében (MAVIR 2021 webhelyen elérhető adatok alapján).

$\mathrm{Az}$ adatok értékelése során megvizsgáltuk a heti jellemző minimális rendszerterhelések alakulását is. Ez azért fontos paraméter, mert ez alá az érték alá sosem megy a rendszerterhelés, ez mutatja tehát, hogy mekkora zsinóráram-igénye volt az adott idószakban a magyar villamosenergia-rendszernek. Az adatok szerint a legnagyobb visszaesést mutató első hullám során sem ment a minimális rendszerterhelés $3100 \mathrm{MW}$ alá (MAVIR 2021). A megfelelő zsinóráram-termelő kapacitások biztosítása tehát ennek megfelelően indokolt.

\section{További országok villamosenergia-igényei a pandémia alatt}

Jogosan merülhet fel a kérdés, hogy az egyes országokban más időpontokban felfutó fertőzöttségi adatok, illetve az eltérő járványkezelési stratégia következtében látható-e eltérés az egyes országok esetében a villamosenergia-igények tekintetében. Ezért az 5. ábrán összevetjük a 2020. évi havi villamosenergia-fogyasztási adatok 2019. évi havi adatokhoz képesti százalékos változását Magyarország, Kína, Németország, Franciaország, Olaszország és Spanyolország tekintetében, majd a 6. ábrán a 2020. év heti villamosenergia-fogyasztási ada- tait mutatjuk meg Magyarországra, illetve az Európai Unióra vonatkozóan. Az 5. ábrán havi bontásban ábrázoljuk a kiválasztott öt európai ország és Kína 2020. évi villamosenergia-fogyasztásának százalékos változását az adott ország 2019. évi azonos havi fogyasztásához viszonyítva. Az így kapott értékek oszlop formátumban jelennek meg az 5. ábrán, valamint ábrázoltuk még az értékekre illesztett hatodfokú polinomokat is pontozott vonalakkal.

Az adatok vizsgálata alapján kijelenthető, hogy az olasz (az 5. ábrán sárgával jelölt) villamosenergia-fogyasztásra volt a legnagyobb hatással a járvány. Az 5. ábrán az is látszik, hogy Olaszországban, Franciaországban és Spanyolországban nemcsak a 2020. évi második negyedévben esik vissza jelentősen a villamosenergia-igény, hanem ez a folyamat már az első negyedév elejétól megfigyelhető. Olaszország és Spanyolország esetében 2020 minden egyes hónapjának villamosenergia-fogyasztása elmarad a 2019. év azonos hónapjának fogyasztásától. A vizsgált európai országok közül a legnagyobb visszaesést egyértelmúen Olaszország szenvedte el, ahol márciusi hónapban $-12,66 \%$, áprilisban pedig $-20,89 \%$ a változás (ENTSO-E 2021 webhelyen elérhető adatok alapján).

Nagyon érdekes elemezni az 5. ábrán Németország lilával és Magyarország pirossal jelölt görbéit is. Egyértelmúen látszik, hogy a két országban hasonló tranziens

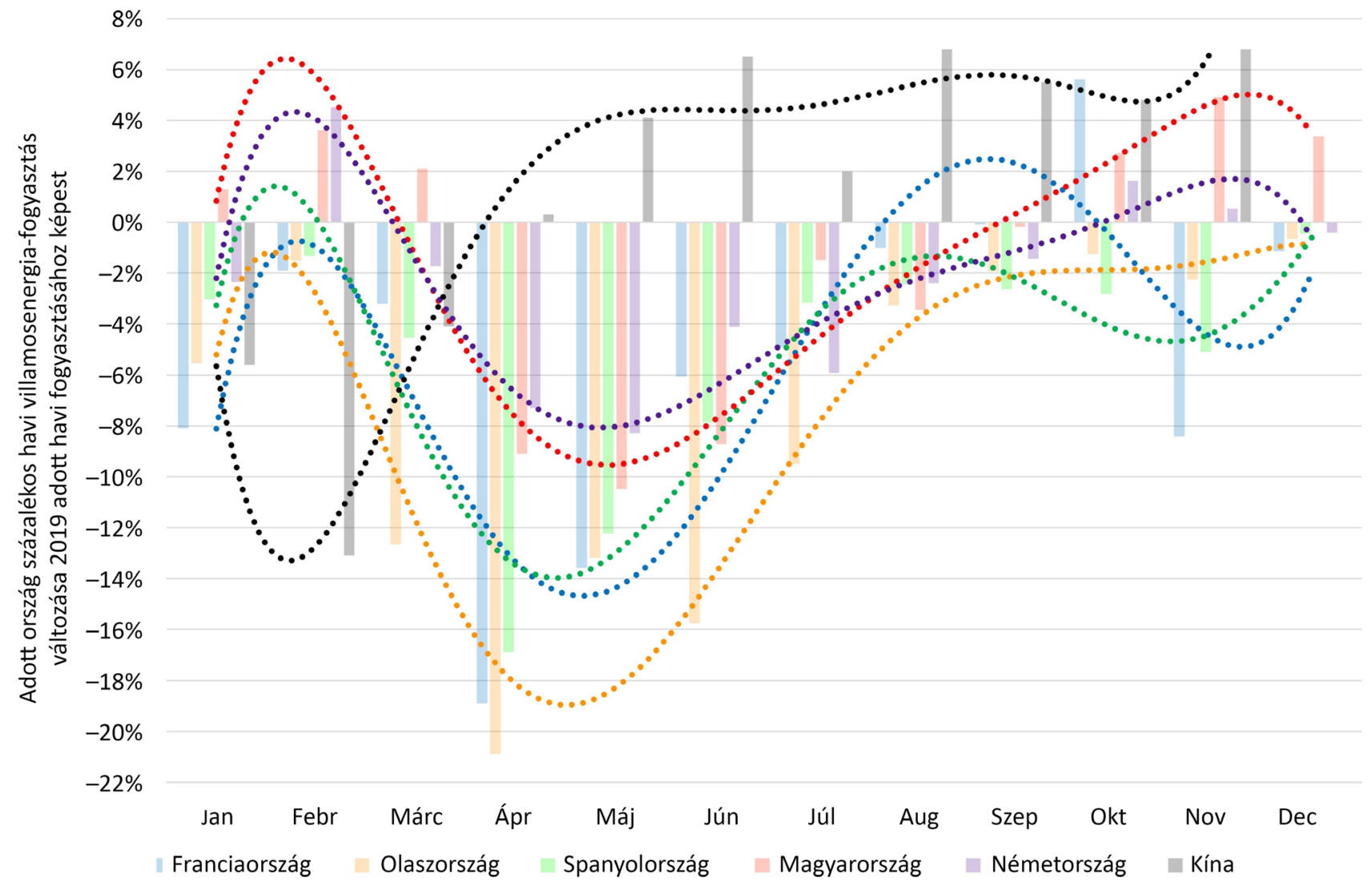

5. ábra | Öt európai ország és Kína havi villamosenergia-fogyasztásának százalékos változása 2020-ban 2019 azonos havi fogyasztásához viszonyítva (ENTSO-E 2021, IEA 2021 és MAVIR 2021 alapján saját szerkesztés) 
játszódott le a villamosenergia-fogyasztás terén, és ido"ben Magyarország gyakorlatilag együtt mozgott Németországgal. Ugyanakkor az 5. ábra jól szemlélteti, hogy amíg Olaszország visszaesése időben megelőzi Spanyolország és Franciaország visszaesését, továbbá az olasz áramigény-csökkenés 4-5 százalékponttal nagyobb is, mint a spanyol és a francia, addig a magyar és a német visszaesés mintegy egy hónapos késleltetéssel követi a francia és a spanyol adatokat. Ahogy korábban említettük, a magyar havi villamosenergia-fogyasztás 2020 utolsó három hónapjában már meghaladta a 2019. évi azonos havi adatokat. Ehhez képest az olasz és a spanyol adatok változása végig a negatív tartományban mozog, a francia pedig ugyan október hónapban pozitív értéket mutat, de 2020 novemberében és decemberében az is visszacsúszik a negatív tartományba. Németország az év végére a 0 változás körüli szúk sávban mozgott.

Ezzel szemben a kínai adatok tekintetében egy teljesen más viselkedést figyelhetünk meg. Az 5. ábrán feketével rajzolt kínai adatok jól mutatják, hogy Kínában már a január jelentős visszaeséssel kezdődött, és a februári csökkenés a 2019. évhez képest 13\%-os. Ugyanakkor a kínai gazdaság 2020 áprilisában átbillent a holtponton, és ezt követően minden hónapban 4-6\%-kal több villamos energiát igényelt, mint 2019-ben (IEA 2021). Ez egyértelmúen azt mutatja, hogy a kínai gazdaság 3-4 hónap alatt lerázta magáról a vírus hatásait, és visszatért a járvány elötti pályára. Az, hogy ezt Kína hogyan volt képes ilyen hatékonyan és rövid időn belül végrehajtani, további részletesebb elemzésre lenne érdemes.

Fontos a magyar villamosenergia-rendszer adatait az összesített európai térképen is elhelyezni, azaz összehasonlítani, hogy hogyan nézett ki Magyarország fogyasztása és az Európai Unió összesített fogyasztása a járvány idején. Ehhez is a már korábban is használt módszert alkalmaztuk, azaz 2020 fogyasztási adatait viszonyítottuk 2019 értékeihez, jelen esetben heti bontásban.

A 6. ábrán bemutatott összevetés alapján megállapítható, hogy a járvány korai időszakában (2-3. negyedév) a hazai görbe szinte százalékra pontosan leköveti az európai összesített fogyasztási görbét (leszámítva a 3. negyedév utolsó 3 hetét), ez alapján egyértelmúen kijelenthető, hogy a járvány nem okozott kiugróan nagyobb hatást a magyar villamosenergia-rendszer fogyasztói oldalán, mint ahogy azt tette a többi európai országban.

Érdekes megemlíteni, hogy az európai adatsor görbéje (feketével) a 4. negyedévben is föleg negatív tartományban maradt, annak ellenére, hogy 6 olyan hét is volt, amikor a 2020. évi adott heti fogyasztás meghaladta a 2019. év adott heti fogyasztását. Ezzel ellentétben a 6. ábra adatai egyértelmúen alátámasztják, hogy a magyar villamosenergia-fogyasztás a 4 . negyedévre már visszatért a válság előttihez közeli pályájára, így a magyar görbe (pirossal) végig pozitív tartományban talál-

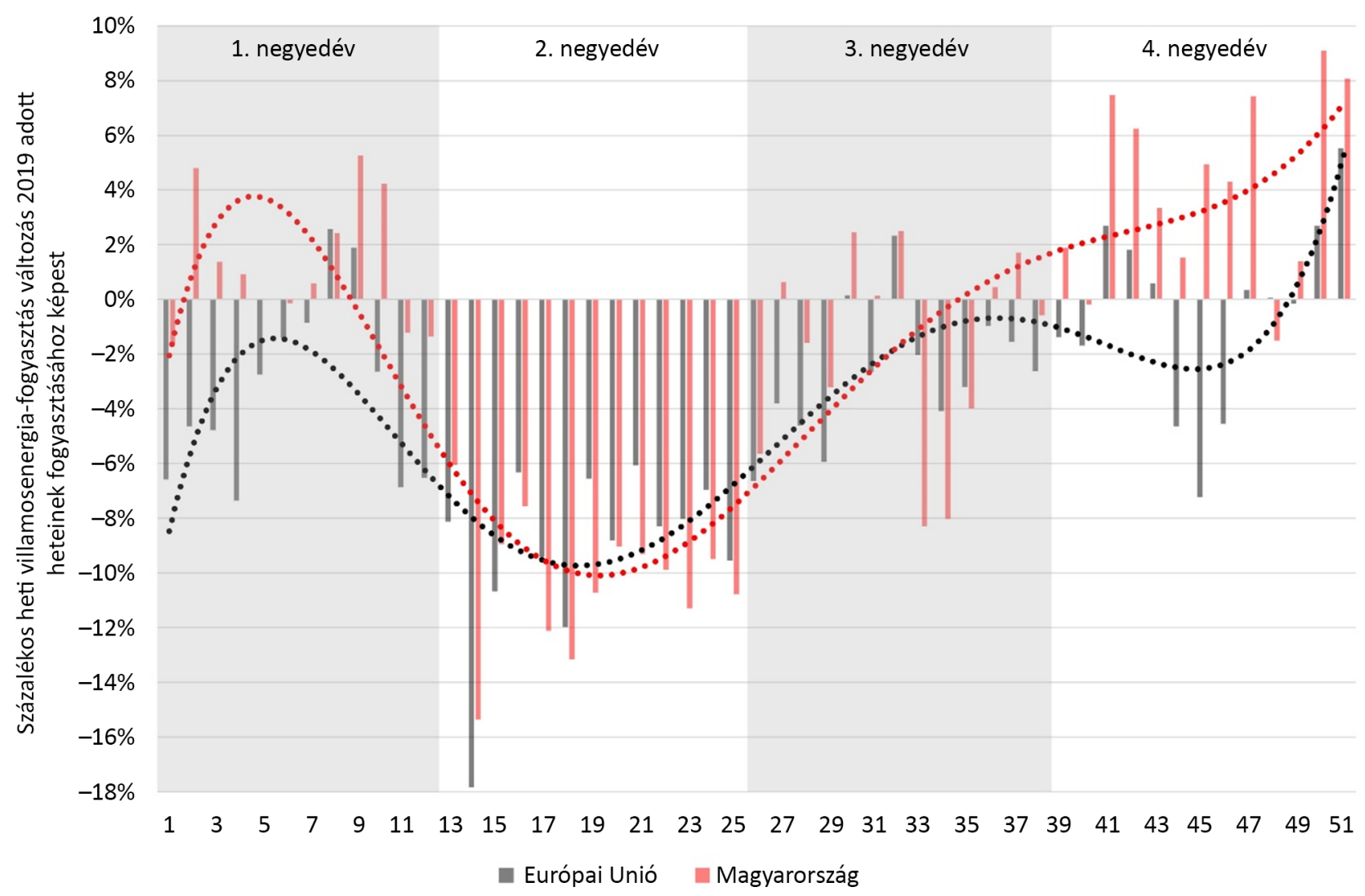

6. ábra

Magyarország heti villamosenergia-fogyasztásának összehasonlítása az európai heti fogyasztással a 2020. év során (ENTSO-E 2021 alapján saját szerkesztés) 
ható, és csak egy olyan hetet lehet találni ebben a negyedévben, amikor a 2020. évi fogyasztás nem haladta meg a 2019. évi azonos heti fogyasztást. Ebben a tekintetben tehát a magyar gazdaság és a magyar villamosenergia-igény az európai összesített adatoktól eltérő viselkedést mutat.

\section{A kritikus villamos energetikai infrastruktúra a járvány idején}

A villamosenergia-rendszer feladata, hogy ellássa a fogyasztókat az igényeiknek megfelelő mennyiségú és minőségü villamos energiával. Mindezt folyamatosan, éjjelnappal, télen-nyáron, a nap 24 órájában, az év 365 napján, évtizedeken keresztül. Ezt a feladatot a villamosenergia-rendszer az erőmúvek, a nagyfeszültségú átviteli hálózat és a közepes és kisfeszültségű elosztóhálózat segítségével látja el. A folyamatos múködéshez szakképzett üzemeltető személyzetre van szükség az erőmúvekben és a villamos hálózatot irányító diszpécserközpontokban is. Ilyen központ múködik országos szinten a MAVIR irányítása alatt, de kisebb felelősségi és feladatkörrel a területi elosztó hálózatot üzemeltető társaságok irányítása alatt is.

Az üzemeltető személyzet járvány miatti kiesése a rendszer bármely eleménél az ellátás folytonosságát és biztonságát veszélyeztetné. Emiatt eminens érdek füződik ahhoz a COVID-19-járvány alatt is, hogy a szakképzett személyzettel való ellátottság fennmaradjon, az üzemeltetés humán feltételei folyamatosan biztosítottak legyenek. A vállalatok Magyarországon - de világszerte is - eltérő stratégiákat alkalmaztak ezen cél teljesítése érdekében. Megemlítendő, hogy az üzemeltetés sok hónapnyi, vagy adott esetben éves időtávlatban nem lenne lehetséges karbantartás nélkül, így a megfelelő karbantartási feladatokra is biztosítani kell egy ilyen különleges helyzetben a szakképzett személyzetet. Ez utóbbi - mint látni fogjuk - nem is feltétlenül volt egyszerü a COVID-19 járvány alatt.

Ahogy fent bemutattuk, a COVID-19-járvány elsó hulláma alatt a vizsgált országokban jelentősen visszaesett a villamosenergia-igény, ugyanakkor az soha, egy pillanatra sem szû́nt meg, tehát az ellátás folyamatosságát biztosítani kellett a legnehezebb időszakokban is. Habár az első hullámban számos ipari üzem termelésének felfüggesztése mellett döntöttek, a villamosenergiaszolgáltatásra továbbra is szükség volt, hiszen az alapinfrastruktúra, a kórházak, az élelmiszeripar, az üzletek, a közlekedés, a háztartások ugyanúgy igényelték a villamos energiát, mint azt megelőzően. Magyarországon a második és a harmadik hullám már növekvő villamosenergia-fogyasztással járt, ami még inkább felhívta a figyelmet az áramellátás biztonságos és folyamatos biztosításának szükségességére.

A kérdés az, hogy egy olyan nagy jelentőségű és folyamatos működésű rendszernek, mint amilyen a villamosenergia-rendszer (benne az erőművekkel, a villamos há- lózattal, rengeteg, térben elszórtan elhelyezkedő berendezéssel, eszközzel), hogyan lehet a járvány körülményei közepette biztosítani a megbízható és biztonságos üzemét.

A különböző erőmúveket magasan képzett szakemberek üzemeltetik, ehhez a dolgozóknak többnyire helyben, az erőmú telephelyén kell tartózkodniuk a feladataik ellátása során. Egyes, az erőmúvek üzemeltetésében szerepet játszó szakemberek olyan specifikus tudással és végzettséggel rendelkeznek, amelyek megszerzése több évet is igénybe vehet. Így az ő esetükben a járvány alatt nem lehetett azzal számolni, hogy ha megbetegednének, majd „beugrik” helyettük valaki. Ezért hazánkban és más helyeken is a villamos energetikai vállalatok úgy határoztak, hogy - amennyire csak lehetséges - megóvják ezeket a munkavállalóikat a megfertőződéstől.

Az átviteli hálózatot üzemeltető MAVIR például úgy döntött (1. a hivatkozott cikkekben), hogy a nélkülözhetetlen szaktudással bíró szakembereit gyakorlatilag teljesen elvágja a külvilágtól, így minimalizálva a fizikai kontaktusaikat. Ezek a szakemberek kéthetes váltásban beköltöztek a MAVIR országos teherelosztó központjának helyet adó épületbe, és nemcsak ott dolgoztak, de ott pihentek, aludtak, és élték életüket. A MAVIR beszámolója szerint ezek a szakemberek megfeszített módon, 8 óra munka, 8 óra pihenés váltásban dolgoztak, és még a múszakváltást is úgy oldották meg, hogy a két múszak személyzete ne találkozzon személyesen egymással. Így azt a kockázatot is elkerülték, hogy az egyes múszakok egymástól, vagy a munkanapok végén esetleg a szakemberek a családtagoktól fertőződjenek meg, tekintettel arra, hogy a kéthetes múszak alatt még a családtagokkal sem találkozhattak az érintettek. Ez a megoldás hatékony, de minden bizonnyal pszichésen erősen megterhelö, és hosszú távon nagyon nehezen fenntartható. A MAVIR megjegyezte, hogy ilyen típusú izolációra az elmúlt 70 évben, még a háború alatt sem volt példa az esetükben, így a COVID-19-járvány ebből a szempontból is rendkívüli helyzetet teremtett (Villanylap 2020).

A paksi atomerőmú a belső közlekedési utak átszervezésével, a higiénés szabályok szigorításával, a nem múszakos személyzet otthoni irodába küldésével, a tömegközlekedés helyett az egyéni közlekedés támogatásával igyekezett elkerülni, hogy akár a hatósági házi karantén alkalmazása, akár a tényleges fertőzések lehetetlenné tegyék a megfelelő üzemeltető személyzet kiállítását.

Az Európai Bizottság szakmai oldalról támogató közösségi kutatóközpont, az EC JRC 2020 tavaszán készített egy rövid összeállítást arról, hogy a különböző európai országokban a több mint 100 atomerőmúvi blokk üzemének fenntartása érdekében milyen intézkedéseket hoztak az erőmútársaságok. A Farrar et al. 2020 hivatkozáson elérhető jelentés a hazánkban is alkalmazott fó intézkedéseket sorolja fel:

- a higiénés elóírások szigorítása,

- a távolságtartás előírása, 
- az üzemeltetés fenntartása szempontjából kritikus munkakörök azonosítása,

- a nem kritikus munkakörökben az otthoni munkavégzés elrendelése, az ilyen dolgozók kizárása a telephelyi munkavégzésből,

- nem létfontosságú látogatások, külső tárgyalópartnerek kizárása a telephelyről,

- tartalék személyzet felállítása és karantén általi védelme annak érdekében, hogy ha szükségessé válik, akkor ez a tartalék mindenképpen bevethető legyen,

- a kritikus személyzet teljes izolálása (mint a MAVIR esetében).

Farrar és munkatársainak tanulmánya (Farrar et al. 2020) beszámol arról is, hogy a francia állami villamos társaság, az EdF jelentése szerint 2 hétig a személyzet 40\%-ának, 12 hétig a személyzet 25\%-ának kiesése még menedzselhető lenne. Nem tudunk arról, hogy a járvány most már közel másfél éve alatt bármely európai atomerőmúvet le kellett volna állítani a kritikus személyzet tömeges megbetegedése miatt.

Az atomerőmúvekben alkalmazható intézkedésekről a Nemzetközi Atomenergia Ügynökség is közzétett információkat (IAEA 2020). A tapasztalatok összegyújtése és megosztása a tagországok között segítette a jó gyakorlatok kialakítását és elterjesztését.

Az IAEA dokumentumában (IAEA 2020) két olyan elemet találtunk, ami talán túlmutat a korábban már említett intézkedéseken:

- az alapvető fontosságú személyzet biztonságának érdekében a munkaidő eltolása, az egyes múszakok idősávjainak megváltoztatása,

- a vezénylő helyiség munkatársaival való kommunikáció alternatív módjainak alkalmazása, a vezénylői munkában a telekommunikációs eszközök korábbinál is intenzívebb alkalmazása.

A COVID-19 válság ellenére a világ mind a 442 nukleáris reaktora üzemképes maradt, az IAEA dokumentum $(I A E A, 2020)$ sem közöl adatot olyan erőműről, amelyet esetleg a személyzet nagyszámú megbetegedése miatt kellett volna leállítani. Reméljük, hogy ez a jövőben is így marad.

Az üzemeltetéshez kapcsolódó kérdések mellett említeni szükséges a karbantartások problémakörét is. Az erőmúvek nagy rendelkezésre állású rendszerek, amelyeket azonban tipikusan éves ciklussal karban kell tartani. Ez bizonyos berendezéseknél nemcsak müszaki szükségszerűség, hanem például garanciális, így jogi és pénzügyi aspektusokhoz is kapcsolódhat.

Az európai erőművek üzemeltetői több olyan esetről számoltak be, hogy járvány miatt leállított közlekedés, illetve a határok lezárása következtében a karbantartás bizonyos fázisaihoz kapcsolódó speciális tudással vagy jogosultsággal bíró karbantartási szakember nem tudott időben az adott erőmű telephelyére utazni, így a karbantartást el kellett halasztani, az üzemi periódust ki kellett nyújtani.
Nagy erőmúveknél külön probléma, hogy az éves vagy kétéves periódusú nagykarbantartás során több száz fös külső személyzetre van szükség, az ő telephelyre történő beléptetésük pedig extra kockázatot jelent. Ennek következtében egyes erőmúvek a nagykarbantartás elnapolása mellett döntöttek, míg mások speciális védelmi intézkedésekkel megvalósították a karbantartásokat.

$\mathrm{Az}$ atomerómúveket típusuktól és kialakításuktól függően jellemzően 12-18-24 havonta le kell állítani fütőelem-átrakás céljából, valamint ilyenkor végzik el az atomerőmü időszakos karbantartási és ellenőrzési tevékenységeit, amelyeket üzem közben nem lehet végrehajtani. Ezen leállások alatt jellemzően több száz további alkalmazott van a telephelyen, akik közül sokan külső vállalkozókhoz tartoznak, és ingázó munkavállalók, ami külön nehézséget okozhat a pandémiás korlátozó intézkedések tekintetében. Az atomerőmúvek üzemeltetői különböző megközelítéseket alkalmaznak a leállások további végrehajtása céljából (1. pl. Farrar et al. 2020). A lehetséges opciók:

- Az erőmú szúkített múködése és a leállás késleltetése, a legszigorúbb pandémiás korlátozó intézkedések lehetséges elkerülése érdekében.

- Megállás csak üzemanyag-átrakás céljából (kiterjedt karbantartási/ellenőrzési tevékenységek nélkül). A rendszeres karbantartási és ellenőrzési tevékenységeket elhalasztják mindaddig, amíg a pandémiás korlátozó intézkedést kellőképpen fel nem oldják.

- A leállás elvégzése a karbantartási és ellenőrzési tevékenységek csökkentett terjedelmével, amelyeket a következő leállásra halasztanak, és/vagy a leállás időtartamának meghosszabbítása a leállás alatt a helyszínre érkező további munkások számának csökkentése érdekében.

- A karbantartás és az átrakás szokásos terjedelmú megvalósítása szigorú járványvédelmi intézkedések mellett.

Ez utóbbi körbe tartozik a paksi atomerőmú is, amelyben az ütemezett karbantartásokat a szigorú járványvédelmi intézkedések mellett, de rendben le tudták bonyolítani.

Minden fent említett nehézség ellenére a magyar és az európai villamosenergia-rendszer üzemképes maradt a COVID-19-járvány alatt, ami nagyon fontos pozitív fejlemény, hiszen a gazdaság és az egészségügy zavartalan múködésének alapvető feltétele a folyamatos és biztonságos villamosenergia-ellátás. A villamosenergia-rendszer mint kritikus infrastruktúra múködtetése, az energiaellátás biztonsága és folyamatossága nemcsak gazdasági és múszaki, hanem alapvető egészségügyi, nemzetbiztonsági, társadalmi és politikai érdek is. A megfelelő szakértelem és a humán erőforrás folyamatos biztosításának fontosságát - különösen a jelenlegi helyzetben - nem lehet túlhangsúlyozni. 


\section{Irodalomjegyzék}

Energetikai Szakkollégium [ESZK] (2020) A koronavírus hatásai a MAVIR-ra. https://www.eszk.org/files/A-korona-hatasai-aMAVIR-ra-beszamolo-(1).pdf

European Network of Transmission System Operators for Electricity [ENTSO-E] (2021) Total load - day ahead / actual. https://transparency.entsoe.eu

Farrar, B., Cihlár, M., Eriksson, A., Ioakeimidou, M., Liessens, A., Manna, G., ... Wastin F (2020) Continued safe operation of nuclear power generation plants during the Covid-19 pandemic, Media and public information monitoring from 13 March -3 April 2020, EC JRC. https://publications.jrc.ec.europa.eu/repository/ handle/JRC120551

International Atomic Energy Agency [IAEA] (2020) IAEA steps up support for Nuclear Facility Operators during COVID-19 crisis. https://www.iaea.org/newscenter/news/iaea-steps-up-supportfor-nuclear-facility-operators-during-covid-19-crisis

International Energy Agency [IEA] (2020) Covid-19 impact on eletricity. https://www.iea.org/reports/covid-19-impact-on-electricity

Központi Statisztikai Hivatal [KSH] (2021) A bruttó hazai termék (GDP) negyedéves volumenindexei. https://www.ksh.hu/stadat_ files/gdp/hu/gdp0086.html

Magyarország Kormánya (2021) Koronavírus statisztika. https://koronavirus.gov.hu

Magyar Villamosenergia-ipari Átviteli Rendszerirányító Zrt. [MAVIR] (2021) Rendszerterhelés terv és tény adatok. https://www.mavir. hu/web/mavir/rendszerterheles

Villanyszerelők lapja [Villanylap] (2020) Beköltöztek a munkahelyükre a MAVIR dolgozói. https://www.villanylap.hu/hirek/5541bekoltoztek-a-munkahelyukre-a-mavir-dolgozoi

A cikk a Creative Commons Attribution 4.0 International License (https://creativecommons.org/licenses/by-nc/4.0/) feltételei szerint publikált Open Access közlemény, melynek szellemében a cikk bármilyen médiumban szabadon felhasználható, megosztható és újraközölhető, feltéve, hogy az eredeti szerző és a közlés helye, illetve a CC License linkje és az esetlegesen végrehajtott módositások feltüntetésre kerülnek. 